\title{
Pressure pain endurance in women with fibromyalgia*
}

\section{Amplitude de dor à pressão em mulheres com fibromialgia}

\author{
Rodrigo Pegado de Abreu Freitas ${ }^{1}$, Sandra Cristina de Andrade ${ }^{1}$, Ranulfo Fiel Pereira Pessoa de Carvalho², Maria Bernardete \\ Cordeiro de Sousa ${ }^{1}$
}

${ }^{*}$ Received from Federal University of Rio Grande do Norte, Natal, RN, Brazil.

\section{ABSTRACT}

BACKGROUND AND OBJECTIVES: Fibromyalgia syndrome is a chronic condition causing spontaneous widespread pain associated with hypersensitivity. This study aimed at investigating the pressure pain endurance in women with fibromyalgia syndrome to determine the range of painful stimulation that an individual with fibromyalgia syndrome can resist acceptably.

METHODS: We conducted an observational, descriptive, crosssectional study with 60 subjects $(51.23 \pm 8$ years), who met the American College of Rheumatology/1990 (ACR) criteria for fibromyalgia syndrome, and 42 healthy volunteers $(48.33 \pm 9$ years) as the control group. Algometry was performed to record pressure pain detection threshold and pressure pain tolerance, and fibromyalgia impact questionnaire was used to determine the impact of fibromyalgia syndrome. Pressure pain endurance was calculated as the arithmetic difference between pressure pain tolerance and pressure pain detection threshold.

RESULTS: A significant difference in fibromyalgia impact questionnaire $(p<0.0001)$, pressure pain detection threshold, and pressure pain tolerance $(\mathrm{p}<0.0001)$ was found between both groups. Furthermore, a significant difference in pressure pain endurance $(\mathrm{p}<0.0001)$ for each of the 18 points identified by ACR was noted between both groups, with the highest range of physical stimulation observed in the control group. A correlation between pressure pain endurance and pressure pain detection threshold $(\mathrm{r}=0.8334 ; \mathrm{p}<0.0001)$ and pressure pain tolerance $(\mathrm{r}=0.8387 ; \mathrm{p}<0.0001)$ was observed in the fibromyalgia syndrome group.

CONCLUSION: Pressure pain endurance of the fibromyalgia syndrome group was extremely lower, when compared with that

\footnotetext{
1. Federal University of Rio Grande do Norte, Natal, RN, Brazil.

2. University Potiguar, Natal, RN, Brazil.

Submitted in August 21, 2014.

Accepted for publication in October 07, 2014

Conflict of interests: none.

Correspondence to:

Rodrigo Pegado de Abreu Freitas

Universidade Federal do Rio Grande do Norte,

Faculdade de Ciências da Saúde do Trairí

Rua Trairí, s/n, Centro

59200-000 Natal, RN, Brasil.

E-mail: rodrigopegado@gmail.com

(C) Sociedade Brasileira para o Estudo da Dor
}

of healthy controls, and may be used as an additional component to measure the disturbance in pain perception and to determine the range of painful stimulation that an individual with fibromyalgia syndrome can acceptably resist.

Keywords: Fibromyalgia, Musculoskeletal pain, Pain measurement, Pain perception, Women.

\section{RESUMO}

JUSTIFICATIVA E OBJETIVOS: A síndrome da fibromialgia é caracterizada por uma condição crônica que causa dor generalizada espontânea associada a hipersensibilidade. Este estudo teve como objetivo investigar a amplitude de dor à pressão em mulheres com síndrome da fibromialgia para determinar o início da sensação dolorosa e o máximo suportado e comparar com controles saudáveis.

MÉTODOS: Foi realizado um estudo observacional, descritivo transversal, conforme os critérios do Colégio Americano de Reumatologia/1990 (ACR), com 60 mulheres (51.23 \pm 8 anos) com diagnóstico de síndrome da fibromialgia e 42 (48.33 9 anos) voluntárias saudáveis como grupo controle. A algometria foi realizada para registro do limiar e tolerância à dor à pressão e aplicado o Questionário de Impacto da Fibromialgia para determinar a funcionalidade. A amplitude de dor à pressão foi calculada como a diferença aritmética entre o registro do limiar e a tolerância à dor à pressão.

RESULTADOS: Foi encontrada diferença significativa no Questionário de Impacto da Fibromialgia e nas variáveis de sensibilidade dolorosa (registro do limiar e tolerância à dor à pressão) entre os grupos $(\mathrm{p}<0,0001)$. Verificou-se diferença significativa $(\mathrm{p}<0,0001)$ na amplitude de dor à pressão para cada um dos 18 pontos identificados pelo ACR entre o grupo síndrome da fibromialgia e o grupo controle, com maior amplitude de dor à pressão no grupo controle. Foi encontrada forte correlação entre a amplitude de dor à pressão com o registro do limiar $(r=0,8334$, $\mathrm{p}<0,0001)$ e a tolerância à dor à pressáo $(\mathrm{r}=0,8387, \mathrm{p}<0,0001)$ no grupo fibromialgia.

CONCLUSÁO: A amplitude da percepção de dor na síndrome da fibromialgia é extremamente baixa quando comparada com controles saudáveis. Portanto, sugere-se que essa relaçáo poderia ser utilizada como um componente adicional para avaliar as perturbaçóes na percepção da dor e determinar o intervalo aceitável de um estímulo doloroso que indivíduo pode suportar.

Descritores: Dor musculoesquelética, Fibromialgia, Mensuração da dor, Mulheres, Percepção da dor. 


\section{INTRODUCTION}

Fibromyalgia syndrome (FMS) is a chronic condition that causes pain, stiffness, and tenderness of muscles, tendons, and joints. It is also characterized by restless sleep, tiredness, fatigue, anxiety, depression, and disturbances in bowel functions ${ }^{1}$. The major symptom could be characterized by spontaneous, widespread, and unexplained pain associated with hypersensitivity, hyperalgesia (decreased mechanical pain threshold), and/or allodynia (pain induced by non-nociceptive stimuli) ${ }^{2}$. Previous studies ${ }^{3,4}$ had described that an abnormality in the central pain processing system results in central amplification of pain signals. The persistence of nociceptive receptors stimulation in the peripheral tissue may lead to plastic alterations in the central nervous system, causing central amplification and increase in pain sensitivity ${ }^{3,4}$. Thus, many methods to assess hypersensitivity in patients with FMS have been developed ${ }^{5-7}$. Apart from a heightened sensitivity to pressure, the responses of patients with FMS to other types of stimuli, such as heat, cold, and electrical stimuli, have been found to be similar to those of the controls ${ }^{8-10}$. Many clinical centers routinely measure pressure pain threshold while assessing chronic pain patients, but not pain range ${ }^{11}$. Pressure pain detection threshold (PPdt) is defined as the point at which a steadily increasing non-painful pressure stimulus turns into a painful pressure sensation. Pressure pain tolerance (PPt) is defined as the highest level of pain that a subject is prepared to tolerate ${ }^{12}$. Pressure pain endurance (PPe) (pain range) is defined as the pressure stimuli because pain is reported (PPdt) until pressure pain increases to a maximum endured level $(\mathrm{PPt})^{13}$. Monitoring of PPe, not only PPdt or the number of tender points, is important to predict the increase or decrease in pain sensitivity by drug or physical therapy ${ }^{5}$. The fact that PPe could be increased without any change in PPdt is important because even with pain, the patient can still perform many daily activities and rehabilitation programs. Similarly, we can increase PPdt without changing PPe. These data are important for physical rehabilitation, including stretching, muscle strength, and aerobic exercise ${ }^{14}$.

The advances in understanding the biology of pain characteristics in FMS could provide rational platforms for treatment target identification and limits for exercise and physical therapy modalities to control chronic musculoskeletal pain. Therefore, this study aimed at investigating PPe in women with FMS to determine the range of painful stimulation that an individual can resist acceptably, and compare it with that of healthy controls.

\section{METHODS}

An observational, descriptive, cross-sectional study was conducted. Patients who met diagnostic criteria ${ }^{14}$ for FMS were recruited from the Medical Clinic of the Onofre Lopes University Hospital and Physiotherapy Clinic at the University Potiguar, Natal, Brazil. Informed consent was obtained from all subjects, and the study protocols complied with ethical guidelines.

A total of 60 adult women aged 32 to 71 years, who met the 1990 American College of Rheumatology (ACR) criteria $^{14}$ for FMS, were recruited. The control group (CT) consisted of 42 healthy volunteers chosen randomly among hospital personnel and teachers.
Inclusion criteria adopted were: (a) medical diagnosis of FMS; (b) ability to understand the study objective and answer the questions; and (c) not participating in physical therapy or rehabilitation programs in the previous 3 months. The CT group met all the inclusion criteria, except diagnosis of FMS and absence of both rheumatic and endocrine diseases. Exclusion criteria for both the groups were: (a) confirmed cognitive deficit; (b) physical and/or organic difficulties that compromised questionnaire application and analgesic tests; (c) endocrine, rheumatic, and/or autoimmune diseases, including chronic fatigue syndrome, chronic pelvic pain, atypical depression, irritable bowel syndrome, rheumatoid arthritis, gout, and lupus; and (d) use of corticosteroids, analgesics, and anti-inflammatory drugs. Subjects were also asked if they had suffered from any stressful experiences in the last 2 weeks, such as quarrels or receiving bad news, or if they had engaged in intense physical activity.

Assessement of pain sensitivity and symptoms of fibromyalgia The experiment was performed in a quiet setting without any interruptions and in isolation from other patients. Algometry was conducted to record PPdt and PPt. A total of 18 tender points were marked with a dermographic pencil and assessed while the patients were in orthostatic position, with their feet slightly separated. Pain sensitivity tests were performed on the 18 identified points by $\mathrm{ACR}^{14}$, perpendicular to the skin at intervals of $5-10 \mathrm{~s}$ by the same qualified examiner. A pressure algometer was used (Pain Diagnostics and Thermography, Great Neck, NY, USA) through a $1 \mathrm{~cm}$ diameter rubber extremity. Pain threshold and tolerance to pressure were quantified in $\mathrm{kg} / \mathrm{cm}^{2}$. The examiner positioned the rubber point above the area to be examined and gradually increased the pressure by $1 \mathrm{~kg} / \mathrm{cm}^{2} / \mathrm{s}$. PPdt was measured when the patient said "I am starting to feel pain." To measure PPt, the patient was asked to bear the maximum amount of pressure from the algometer and use the sentence "Stop, I cannot take anymore" when she could no longer tolerate pain. Patients were asked to use these exact sentences for standardization of the test. PPe was calculated as the arithmetic difference between PPt and PPdt, i.e., PPt - PPdt=PPe.

Functional capacity was evaluated using the Brazilian version of the Fibromyalgia Impact Questionnaire (FIQ) ${ }^{15}$, which is a selfadministered questionnaire that measures the functional aspects of the patient over the last few weeks. The FIQ contains three Likert-scale-type questions (levels of response) and seven visual analog questions. All the scales vary from 1 to 10 and a high score indicates negative impact and more severe symptoms. Total FIQ score is graded from 1 to 100 points. Higher scores are related to greater impact of the disease on patients' functionality and a corresponding reduction in their quality of life ${ }^{15}$.

\section{Statistical analysis}

Statistical analysis was performed using SPSS 19.0 and GraphPad Prism 5 (GraphPad Software Inc. 2009). Quantitative parameters were described by mean (Mn) and standard deviation (SD). The first step of the statistical analysis was to test the normal distribution using Kolmogorov-Smirnov test. Mann-Whitney test was employed to compare inter-group means and Spearman test was used to determine the correlation between PPe and PPt as 
well as between PPe and PPdt in the FMS group. The value of $\mathrm{p}$ for statistically significant results was set at $\leq 0.05$.

The Research Ethics Committee of the Federal University of Rio Grande do Norte has approved all procedures described in this study $(274 / 2010)$.

\section{RESULTS}

No difference in age between groups was found. A significant increase in FIQ scores was observed in the FMS group $(\mathrm{p}<0.0001)$ (Table 1). The FMS group showed a decrease in PPdt and $\mathrm{PPt}$, indicating extreme sensitivity to pain. Furthermore, a significant decrease in the values of PPdt (FMS $=1.88 \pm 0.45 \mathrm{~kg} /$ $\left.\mathrm{cm}^{2} ; \mathrm{CT}=4.76 \pm 1.2 \mathrm{~kg} / \mathrm{cm}^{2}\right)$ and $\mathrm{PPt}\left(\mathrm{FMS}=2.49 \pm 0.52 \mathrm{~kg} / \mathrm{cm}^{2}\right.$; $\left.\mathrm{CT}=5.91 \pm 1.5 \mathrm{~kg} / \mathrm{cm}^{2}\right)$ was found $(\mathrm{p}<0.0001)$ (Table 1$)$.

Table 1. Age and differences in pain and functionality between fibromyalgia and control groups

\begin{tabular}{lccc}
\hline \multicolumn{4}{c}{ Groups } \\
Variables & $\begin{array}{c}\text { Fibromyalgia } \\
(\mathrm{n}=60)\end{array}$ & $\begin{array}{c}\text { Control } \\
(\mathrm{n}=42)\end{array}$ & Value-p \\
\hline Age & $51.23 \pm 8$ & $48.33 \pm 9$ & 0.1178 \\
FIQ & $68.96 \pm 16.4$ & $18.12 \pm 12.3$ & $<0.0001^{*}$ \\
PPdt & $1.88 \pm 0.45$ & $4.76 \pm 1.2$ & $<0.0001^{*}$ \\
PPt & $2.49 \pm 0.52$ & $5.91 \pm 1.5$ & $<0.0001^{*}$ \\
\hline
\end{tabular}

Mann-Whitney test. FIQ; Fibromyalgia Impact Questionnaire; PPdt: pressure pain detection threshold; PPt: pressure pain tolerance; Pain values in $\mathrm{kg} / \mathrm{cm}^{2}$. *Significant at $5 \%$.
Table 2 shows significant differences $(\mathrm{p}<0.0001)$ between FMS and CT groups in PPdt, PPt, and PPe for each of the 18 points examined by ACR; values of all variables were significantly lower for the FMS group. PPe of FMS group showed a significant decrease $(\mathrm{p}<0.0001)\left(0.60 \pm 0.09 \mathrm{~kg} / \mathrm{cm}^{2}\right)$, when compared with that of CT groupe $\left(1.14 \pm 0.3 \mathrm{~kg} / \mathrm{cm}^{2}\right)$, with the highest range of physical stimulation found in the CT groupe (Figure 1). A strong positive correlation between PPe and PPdt $(r=0.8334$; $\mathrm{p}<0.0001)$ as well as between PPe and $\operatorname{PPt}(\mathrm{r}=0.8387 ; \mathrm{p}<0.0001)$ was noted in the FMS group (Figure 2).

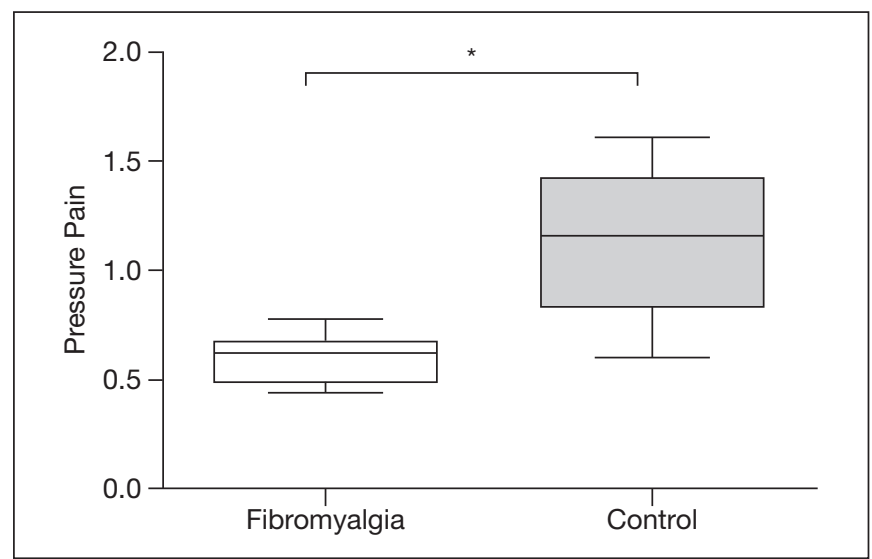

Figure 1. Boxplot comparing pressure pain endurance means between fibromyalgia and control groups

Pressure pain values in $\mathrm{kg} / \mathrm{cm}^{2}$. ${ }^{*}$ Significance: $\mathrm{p}<0.0001$

Table 2. Pressure pain means for each of the18 points identified by ACR between fibromyalgia and control group

\begin{tabular}{|c|c|c|c|c|c|c|c|}
\hline \multirow[b]{2}{*}{ Tender Points } & \multicolumn{3}{|c|}{ Fibromyalgia } & \multicolumn{3}{|c|}{ Control } & \multirow[b]{2}{*}{$p$ value } \\
\hline & PPdt & PPt & $\mathrm{PPe}$ & PPdt & PPt & $\mathrm{PPe}$ & \\
\hline R Low Cervical & 1.55 & 2.14 & 0.59 & 2.54 & 3.39 & 0.85 & $<0.0001$ \\
\hline R Second Rib & 1.28 & 1.78 & 0.5 & 3.24 & 4.00 & 0.76 & $<0.0001$ \\
\hline L Second Rib & 1.24 & 1.68 & 0.44 & 3.32 & 4.12 & 0.8 & $<0.0001$ \\
\hline R Knee & 2.37 & 3.01 & 0.64 & 5.78 & 7.39 & 1.61 & $<0.0001$ \\
\hline L Knee & 2.60 & 3.23 & 0.63 & 6.28 & 7.69 & 1.41 & $<0.0001$ \\
\hline L Occiput & 1.51 & 2.01 & 0.5 & 3.74 & 4.56 & 0.82 & $<0.0001$ \\
\hline R Occiput & 1.45 & 1.93 & 0.48 & 3.93 & 4.82 & 0.89 & $<0.0001$ \\
\hline R Supraspinatus & 2.04 & 2.82 & 0.78 & 5.90 & 7.07 & 1.17 & $<0.0001$ \\
\hline L Gluteal & 2.29 & 2.91 & 0.62 & 6.13 & 7.61 & 1.48 & $<0.0001$ \\
\hline R Gluteal & 2.15 & 2.89 & 0.74 & 6.29 & 7.70 & 1.41 & $<0.0001$ \\
\hline L Greater T & 2.64 & 3.30 & 0.66 & 5.85 & 7.09 & 1.24 & $<0.0001$ \\
\hline R Greater T & 2.40 & 3.17 & 0.77 & 5.47 & 6.79 & 1.32 & $<0.0001$ \\
\hline
\end{tabular}

Results of Mann-Whitney test. Significant at $5 \%$.

R: right; L: left; Lat: lateral; Greater T: Greater trochanter; PPe: pressure pain endurance; PPe: pressure pain tolerance; PPdt: pressure pain detection threshold. Pressure pain values in $\mathrm{kg} / \mathrm{cm}^{2}$. There is a significant intergroup PPdt, PPt and PPe difference for each of the18 points identified by ACR ${ }^{14}$. 


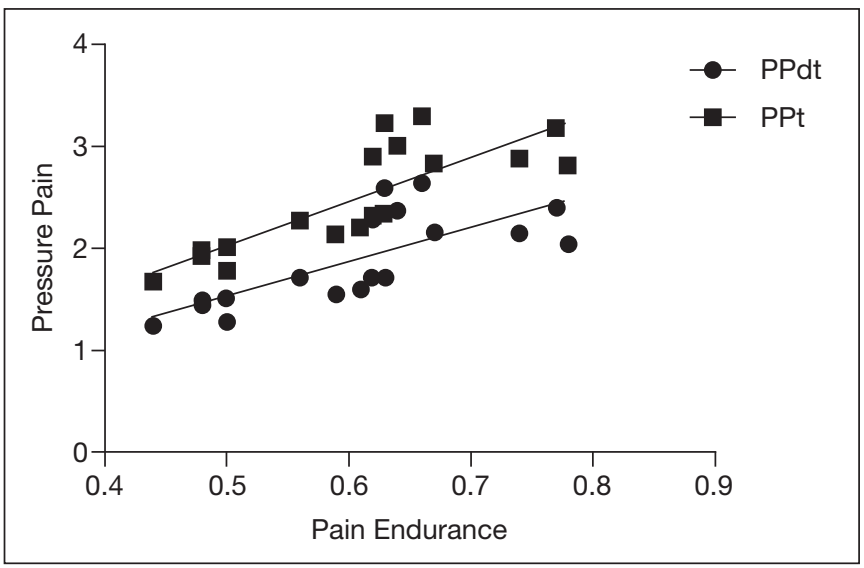

Figure 2. Spearman correlation between pressure pain endurance with pressure pain tolerance $(r=0.8387 ; p<0.0001)$ and pressure pain detection threshold $(r=0.8334 ; p<0.0001)$ in fibromyalgia group. It was used the 18 points identified by $\mathrm{ACR}^{14}$

Pressure pain values in $\mathrm{kg} / \mathrm{cm}^{2}$.

\section{DISCUSSION}

When compared with the CT group, PPe (pain range) of the FMS group was significantly reduced. This indicated that FMS led to a significant decrease in PPe that was extremely lower, when compared to that of healthy controls, and was associated with the initial painful pressure sensation and maximum endured level.

Pain perception was clearly altered in the FMS group, resulting in lower functionality, impairment of physical activities, and increased depressive or anxiety states. An understanding of PPe in FMS could provide rational platforms for treatment and limits for exercise and physical therapy modalities to control chronic musculoskeletal pain ${ }^{2}$.

Psychological and biological factors that may be responsible for these alterations have been fairly discussed. Some authors have described that in normal pain process, perception of pain involves two main groups of neural pathways, namely, ascending and descending pathways ${ }^{4}$. The peripheral nerves transmit sensory signals, including nociceptive stimuli, to the spinal cord for transmission via the ascending nociceptive pathway to the brain for processing. Descending pain modulatory pathways send both facilitatory and inhibitory signals from the encephalon to the spinal cord and periphery, either increasing or decreasing the "volume control" on incoming nociceptive signals reaching the brain $^{2,4}$. In patients with FMS, these two pain pathways appear to operate abnormally, resulting in central amplification of pain signals and lower $\mathrm{PPe}^{4,9}$.

We suggest that even with low PPdt, patients with FMS may present an improved PPt. Therefore, patients with FMS should be given better support in physical therapy, including aerobic exercises, muscle strengthening, electrotherapy, and hydrothera$\mathrm{py}^{3,8}$. Although regular exercise is clearly associated with higher pain tolerance, pain thresholds are affected more ambiguously, possibly producing clinical implications. Tesarz et al. ${ }^{16}$ indicated that regular physical activity is associated with specific alterations in pain perception. Studies on the effect of physical exercise on pain patients have demonstrated a consistent impact on quality of life and functioning without improvement in pain scores. Thus, in the exercise treatment for pain patients, it may be advisable to focus on the development of pain-coping skills that would affect tolerance, rather than direct alleviation of $\mathrm{PPe}^{9,16}$. With this strategy, it may be possible to increase PPe in patients with FMS and improve their quality of life and functionality. Further research is needed to clarify the relationship between modifications in pain perception, psychological factors, and neurobiological processes in patients with FMS.

\section{CONCLUSION}

Patients with FMS have reduced functionality and decreased $\mathrm{PPe}$, indicating that this variable should be used as an additional component to measure the disturbance in pain perception and to determine the range of painful stimulation that an individual can resist acceptably. Thus, the knowledge of PPe in patients with FMS may provide rational platforms for treatment and limits for exercise and physical therapy modalities, improving both quality of life and functionality.

\section{REFERENCES}

1. Jahan F, Nanji K, Qidwai W, Qasim R. Fibromyalgia syndrome: an overview of pathophysiology, diagnosis and management. Oman Med J. 2012;27(3):192-5.

2. Clauw DJ. Fibromyalgia: an overview. Am J Med. 2009;122(12 Suppl):S3-S13.

3. Yunus MB. Central sensitivity syndromes: a new paradigm and group nosology for fibromyalgia and overlapping conditions, and the related issue of disease versus illness. Semin Arthritis Rheum. 2008;37(6):339-52.

4. Clauw DJ, Arnold LM, McCarberg BH; FibroCollaborative. The science of fibromyalgia. Mayo Clin Proc. 2011;86(9):907-11.

5. Jespersen A, Dreyer L, Kendall S, Graven-Nielsen T, Arendt-Nielsen L, Bliddal H, et al. Computerized cuff pressure algometry: A new method to assess deep-tissue hypersensitivity in fibromyalgia. Pain. 2007;131(1-2):57-62.

6. Marques AP, Assumpção A, Matsutani LA, Pereira CA, Lage L. Pain in fibromyalgia and discrimination power of the instruments: Visual Analog Scale, Dolorimetry and the McGill Pain Questionnaire. Acta Reumatol Port. 2008;33(3):345-51.

7. Ablin K, Clauw DJ. From fibrositis to functional somatic syndromes to a bell-shaped curve of pain and sensory sensitivity: evolution of a clinical construct. Rheum Dis Clin North Am. 2009;35(2):233-51.

8. Marques AP, Ferreira EA, Matsutani LA, Pereira CA, Assumpção A. Quantifying pain threshold and quality of life of fibromyalgia patients. Clin Rheumatol. 2005;24(3):266-71.

9. Helfenstein Junior M, Goldenfum MA, Siena CA. Fibromyalgia: clinical and occupational aspects. Rev Assoc Med Bras 2012;58(3):358-65.

10. Petzke F, Clauw DJ, Ambrose K, Khine A, Gracely RH. Increased pain sensitivity in fibromyalgia: effects of stimulus type and mode of presentation. Pain. 2003;105(3):403-13.

11. Nielsen LA, Henriksson KG. Pathophysiological mechanisms in chronic musculoskeletal pain (fibromyalgia): the role of central and peripheral sensitization and pain disinhibition. Best Pract Res Clin Rheumatol. 2007;21(3):465-80.

12. Egloff N, Klingler N, von Känel R, Cámara RJ, Curatolo M, Wegmann B, et al. Algometry with a clothes peg compared to an electronic pressure algometer: a randomized cross-sectional study in pain patients. BMC Musculoskelet Disord. 2011;25(12):174.

13. Dagtekin O, König E, Gerbershagen HJ, Marcus H, Sabatowski R, Petzke F. [Measuring pressure pain thresholds. Comparison of an electromechanically controlled algometer with established methods]. Schmerz. 2007;21(5):439-44. German.

14. Wolfe F, Smythe HA, Yunus MB, Bennett RM, Bombardier C, Goldenberg DL, et al. The American College of Rheumatology 1990 Criteria for the Classification of Fibromyalgia. Report of the Multicenter Criteria Committee. Arthritis Rheum. 1990;33(2):160-72.

15. Marques AP, Santos AM, Assumpçáo A, Matsutani LA, Lage LV, Pereira CA. Validation of the brazilian version of the Fibromyalgia Impact Questionnaire (FIQ). Rev Bras Reumatol. 2006;46(1):24-31.

16. Tesarz J, Schuster AK, Hartmann M, Gerhardt A, Eich W. Pain perception in athletes ompared to normally active controls: a systematic review with meta-analysis. Pain 2012;153(6):1253-62. 